\title{
MicroRNA-130b attenuates dexamethasone-induced increase of lipid accumulation in porcine preadipocytes by suppressing PPAR- $\gamma$ expression
}

\author{
Shifeng Pan ${ }^{1,2, *}$, Yixin Cui ${ }^{1, *}$, Xuan Dong ${ }^{1, *}$, Tangjie Zhang ${ }^{1,2}$ and Hua Xing ${ }^{1,2}$ \\ ${ }^{1}$ College of Veterinary Medicine, Yangzhou University, Yangzhou, Jiangsu, 225009, P. R. China \\ ${ }^{2}$ Jiangsu Co-Innovation Center for the Prevention and Control of Important Animal Infectious Disease and Zoonoses, \\ Yangzhou, Jiangsu, 225009, P. R. China \\ *These authors have contributed equally to this work \\ Correspondence to: Shifeng Pan, email: pan.sf@163.com \\ Keywords: miR-130b, PPAR- $\gamma$, porcine preadipocytes, lipid accumulation, dexamethasone \\ Received: July 14, $2017 \quad$ Accepted: August 17, $2017 \quad$ Published: September 27, 2017 \\ Copyright: Pan et al. This is an open-access article distributed under the terms of the Creative Commons Attribution License 3.0 \\ (CC BY 3.0), which permits unrestricted use, distribution, and reproduction in any medium, provided the original author and source \\ are credited.
}

\section{ABSTRACT}

In this study, two experiments were conducted to determine the role of $\mathbf{m i R}-130 \mathrm{~b}$ in dexamethasone (DEX)-induced lipid accumulation. Porcine preadipocytes were treated with $10^{-6} \mathrm{M}$ DEX for $48 \mathrm{~h}$ to investigate effects of DEX in lipid accumulation. Next, in order to illustrate the regulatory role of miR-130b on lipid accumulation induced by DEX, miRNA scrambled control (miR-SC), miR-130b overexpression plasmid and $\mathbf{m i R - 1 3 0 b}$ inhibitor were respectively transfected into porcine preadipocytes at 24 $h$ before DEX treatment for $48 \mathrm{~h}$ (miR-SC-DEX, miR-130b-DEX and miR-130b-inhibitorDEX). Results showed that $10^{-6}$ M DEX significantly increased TG concentration and expression of $\mathrm{miR-130b}$ as well as its target gene peroxisome proliferatoractivated receptor- $\gamma$ (PPAR- $\gamma$ ). Dual-luciferase reporter assays indicated that PPAR- $\gamma$ expression was negatively regulated by miR-130b, while this effect was abolished with cotransfection of miR-130b and miR-130b inhibitor. In addition, miR-130b-DEX did not change cell proliferation but significantly decreased TG concentration and PPAR- $\gamma$ expression compared to miR-SC-DEX cells, while miR-130b-inhibitor-DEX cells presented opposite results. Furthermore, miR-130b-DEX significantly reduced expression of PPAR- $\gamma$ downstream factor perilipin 1 as well as adipogenesis genes fatty acid synthase, acetyl coenzyme A carboxylase, $11 \beta$ hydroxysteroid dehydrogenase type 1 and fat mass and obesity-associated gene, whereas expression as well as enzyme activity of adipose triglyceride lipase and hormone-sensitive lipase were greatly increased. Overall, these results clarified the role of miR-130b in DEX-induced increase of lipid accumulation in porcine preadipocytes, suggesting that miR-130b might be deemed as a novel potential therapeutic target for DEX-induced increase of lipid accumulation, and consequently provide new insights in obesity control.

\section{INTRODUCTION}

Worldwide obesity epidemic has increased explosively over the last several decades, which rapidly predispose obese individuals to a greater risk for non-alcoholic fatty liver disease, type II diabetes and atherosclerotic cardiovascular diseases [1-3], therefore, a better understanding of molecular mechanisms that contribute to obesity is crucial for its prevention and treatment. Pig (Sus scrofa) is the most powerful domestic animal in fat deposition, furthermore, the pig is a nonprimate mammal that closely resembles man in anatomy, 
physiology and genetics, and can be served as the most desirable animals for studying obesity and metabolic related diseases $[4,5]$. In addition, in the animal husbandry and veterinary industry, a reduction of subcutaneous fat deposition is a major goal in the continued improvement of meat animals. As a result, a deeper understanding of fat deposition in porcine adipose tissue facilitates both meat production industry and biomedical research.

Pathophysiologic increase in fat mass with altered adipogenesis and lipolysis, is the direct reason of obesity [6]. This process can be affected by numerous factors, besides genetic and nutritional factors, hormones related to lipid metabolism play important roles in the development of lipid deposition, among which glucocorticoids (GCs) steroids that were released from the adrenal cortex upon activation of the hypothalamic-pituitaryadrenal axis in response to stress [7], are most important. Numerous studies demonstrated that depending on the physiological conditions, exogenous GCs can cause either direct or indirect effects on the lipid metabolism and leads to adipogenic and lipolytic actions in adipose tissues [8-12], suggesting that the pivotal role of these stress hormones in lipid metabolism is much more controversial. Therefore, the exact role of GCs steroids in lipid accumulation of porcine preadipocytes needs to be further described.

Fat deposition in adipose tissue is contributed by both cell number increase through proliferation and cell size increase through lipid accumulation of adipocytes $[13,14]$, the latter refers to adipogenesis and is highly orchestrated by multiple transcriptional factors, among which peroxisome proliferators-activated receptor- $\gamma$ (PPAR- $\gamma$ ) is the primary one $[15,16]$. PPAR- $\gamma$ knock-out mice has been shown decreased fat mass [17], whereas overexpression of PPAR- $\gamma$ show induced adipogenesis [18]. Thus, PPAR- $\gamma$ is considered as a means of controlling adipose tissue mass, thereby regarding as a rational therapeutic target for the treatment of obesity. However, whether GCs-induced lipid accumulation is associated with changed PPAR- $\gamma$ expression needs to be further explored, so as to search for the effective therapeutical target against GCs steroids induced obesity.

In addition to the massive understanding of the protein-coding genes in lipid accumulation, miRNAs stand out as a critical contributing factor just in recent decades. They are a class of non-coding, regulatory RNA molecules, 21-24 nucleotides in length and regulate target genes expression by inducing cleavage of mRNAs or via inhibition of protein translation [19]. Therapeutic means altering miRNAs levels are being explored as novel strategies for clinical use in various diseases [20]. Nowadays, accumulating evidence have indicated that miRNAs are abnormally expressed in adipose tissue and act as either promote [21-23] or inhibit adipogenesis genes expression [24-26]. Therefore, it has been proposed that miRNAs are able to serve as novel targets for anti-obesity therapies by affecting the lipid metabolism process.
miR-130b is a novel lipid metabolism related miRNA that has been found to be involved in several biological processes. Overexpression of miR-130b has been shown to impair adipogenesis in the human primary preadipocytes and 3T3-L1 cell lines [27]. In our previous study, we also demonstrated that miR-130b inhibited adipogenesis in Meishan pigs [28], supporting that miR-130b has an important inhibiting effect on lipid metabolism in adipose tissues. In addition, it has been reported that the expression of miR-130b is extremely sensitive to GCs treatment [29], demonstrating the interaction between GCs and miR-130b. However, until now, very little research has been done to determine the effect of miR-130b treatment on the GCs induced lipid accumulation in porcine preadipocytes and to investigate the therapeutic potential of modulating miR-130b level to treat obesity.

Therefore, the aim of the present study was to investigate the effect of DEX on lipid metabolism in porcine preadipocytes, and to further determine the effect of prior transfection with miR-130b on the lipid deposition induced by DEX and to explore the potential mechanisms. These findings may be helpful in improving the pork quality and in searching for treatment strategies of obesity.

\section{RESULTS}

\section{Effect of $10^{-6} \mathrm{M}$ DEX on the differentiation induction and lipid metabolism related gene expression of porcine preadipocytes}

Adipogenic differentiation was induced when the cell density of porcine preadipocytes reached to $85 \%$ $90 \%$ confluence (Figure 1A-1B), and it can be obviously observed under the microscope that when compared with control cells, the number and the size of lipid droplets in adipocyte increased significantly (Figure 1C-1F) in $10^{-}$ ${ }^{6} \mathrm{M}$ DEX treated cells (Structural formula is shown in Figure 1G), suggesting that the adipogenic differentiation of adipocytes was successfully induced. Furthermore, when compared with control cells, $10^{-6} \mathrm{M}$ DEX did not change the cell viability (Figure $1 \mathrm{H}$ ), while significantly increased the TG concentration in porcine preadipocytes (Figure 1I) basing on both the Oil red $\mathrm{O}$ staining and TG quantitative detection kit results. These above results indicated that $10^{-6} \mathrm{M}$ DEX increased lipid accumulation in porcine preadipocytes, and this was mainly caused by induced differentiation rather than adipocyte proliferation.

In addition, when compared to control cells, $10^{-6} \mathrm{M}$ DEX notably increased PPAR- $\gamma$ and its target genes FAS and ACC mRNA expression in porcine preadipocytes (Figure 1J). Furthermore, the protein levels of PPAR- $\gamma$, FAS and ACC were also significantly increased (Figure $1 \mathrm{~K}-1 \mathrm{~L}$ ), suggesting that PPAR- $\gamma$ plays an important role in the differentiation induction of porcine preadipocytes under the treatment with $10^{-6} \mathrm{M} \mathrm{DEX}$. 


\section{Effect of $10^{-6} \mathrm{M}$ DEX on the expression of miRNAs targeting PPAR- $\gamma$}

Several computational miRNA target-gene prediction tools (http://www.targetscan.org/, http:// www.microrna.org, http://www.ebi.ac.uk/enrightsrv/ microcosm/) were used to identify possible candidates targeting PPAR- $\gamma$. RT-qPCR method was used to detecte the expression of miRNAs and the results showed that only miR-130b and miR-128 expression was significantly increased in $10^{-6} \mathrm{M}$ DEX treated adipocytes when compared with control cells, while miR-130a, miR-27b and miR-301 expression showed no obvious change, indicating that miR-130b expression is sensitive to $10^{-6}$ M DEX and there may be a certain relationship between miR-130b and PPAR- $\gamma$ (Figure 2).

\section{Validation of ssc-miR-130b targeting PPAR- $\gamma$ 3'-UTR}

The 3'-UTR of PPAR- $\gamma$ mRNA contains the only one predicted miR-130b target site corresponding perfectly to nucleotides 2-8 of mature miRNA (Figure $3 \mathrm{~A})$. The seed target sequence is highly conserved in many species including pig, human, mouse, rat, cow, sheep, chicken, and dog (Figure 3B). To examine the relationship between miR-130b and PPAR- $\gamma$ and confirm that the predicted seed sequence for miR-130b is mediating the repressive effect on PPAR- $\gamma$ translation, we generated a luciferase reporter DNA construct containing the pig 387 bp PPAR- $\gamma$ 3'-UTR with a miR-130b putative binding site and pig miR-130b overexpression plasmid (ssc-miR-130b), both of which were cotransfected into HeLa-229 cells that have low levels of endogenous miR-130b, ssc-miR-SC plasmid was used as a negative control. Luciferase activity was decreased significantly in the presence of ectopic expression of miR-130b at $24 \mathrm{~h}$ when compared with miR-SC cells, in addition, transfection of miR-130b inhibitor in HeLa-229 cells relieved the repression of the luciferase reporter activity cansed by miR-130b overexpression (Figure 3C). Taken together, these data confirmed the presence of a functional and direct miR-130b target site in the 3'-UTR of PPAR $-\gamma$ mRNA.

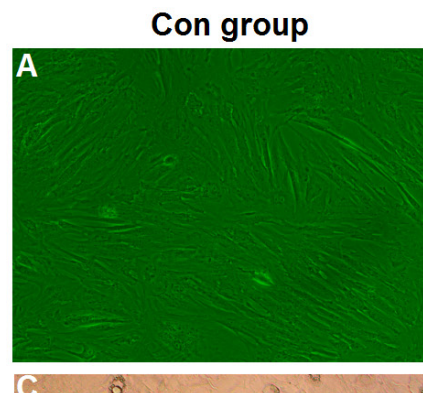

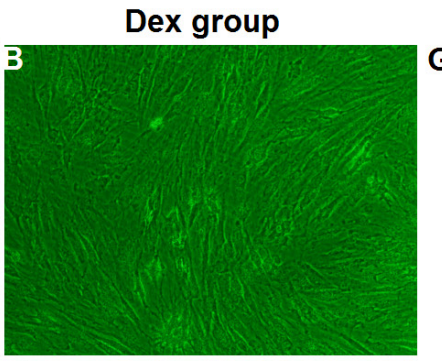

\section{G}

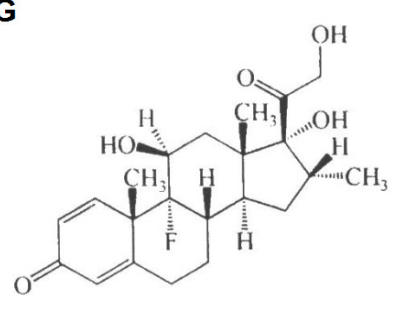

H
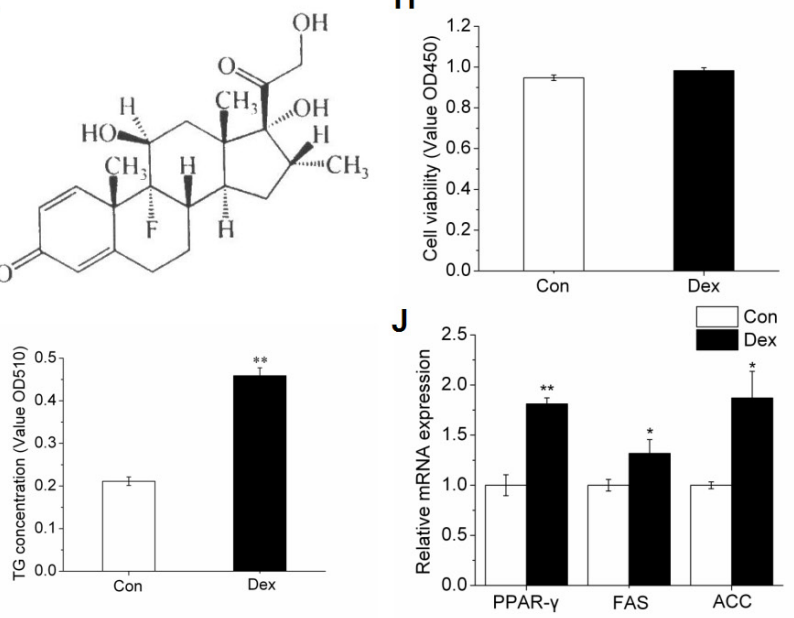

K
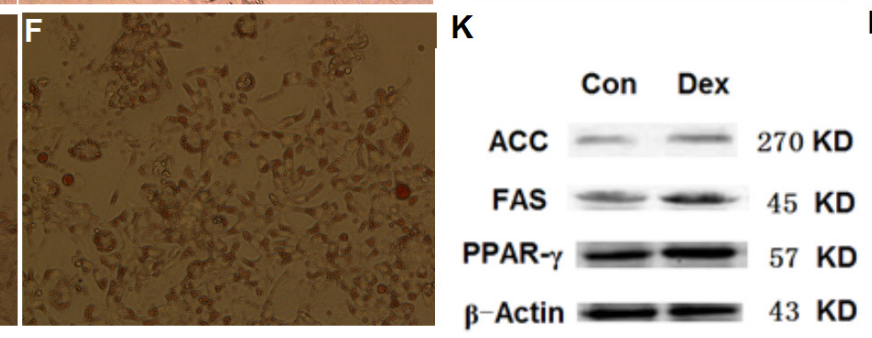

$\mathbf{L}$

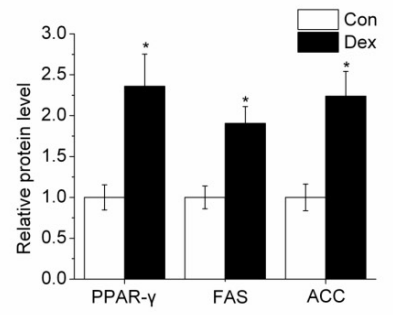

Figure 1: Effect of $10^{-6} \mathrm{M}$ DEX on the differentiation induction and lipid metabolism related gene expression of porcine preadipocytes. (A-B): Porcine preadipocytes reached to $85 \%-90 \%$ confluence $(\times 200)$. (C-D): Lipid droplets under the microscope after differentiation for $48 \mathrm{~h}(\times 200)$. $(\mathbf{E}-\mathbf{F})$ : Oil Red-O staining with adipocytes, the red parts are lipid droplets $(\times 200)$. (G): Structural formula of DEX. (H): The cell proliferation and activity. (I): TG quantification. (J): mRNA expression of PPAR- $\gamma$, FAS and ACC. (K-L): Protein levels of PPAR- $\gamma$, FAS and ACC. Con: control adipocytes. Dex: $10^{-6} \mathrm{M}$ DEX adipocytes. The values shown represent the means \pm SEM, $\mathrm{n}=6 /$ group. ${ }^{*} P<0.05$ vs. Con cells, ${ }^{* *} P<0.01$ vs. Con cells. 


\section{MiR-130b targets PPAR- $\gamma$ and regulates lipid metabolism}

Based on the relationship between miR-130b and PPAR- $\gamma$, it was then important to further validate the role of miR-130b in regulating target gene PPAR- $\gamma$ by using gain-of-function and loss-of-function experiments. In the present study, gain-of-function and loss-offunction experiments was performed by $100 \mathrm{ng}$ miR$130 \mathrm{~b}$ overexpression plasmid and miR-130b-inhibitor, respectively. Results showed that when compared with miR-SC-DEX cells, the number and the size of lipid droplets in adipocyte reduced significantly in miR-130bDEX treated cells, while miR-130b-inhibitor-DEX cells showed the opposite results (Figure 4A-4F). Furthermore, both the Oil red $\mathrm{O}$ staining and TG quantitative detection kit results showed that miR-130b-DEX significantly reduced the TG concentration when compared with miR-SC-DEX cells, while miR-130b-inhibitor-DEX significantly increased the TG concentration, though the cell proliferation and activity were not affected among the three groups (Figure 4G-4K). PCR results demonstrated that miR-130b expression in miR-130b-DEX cells was almost forty-five times higher than miR-SC-DEX cells, while miR-130b-inhibitor-DEX cells showed much lower expression of miR-130b (Figure 4L). In addition, higher expression of miR-130b in miR-130b-DEX cells significantly reduced the PPAR- $\gamma$ mRNA and protein expression when compared with miR-SC-DEX group, while miR-130b-inhibitor-DEX was able to reverse this trend significantly (Figure 4M-4O). These data further suggest that miR-130b is able to target PPAR- $\gamma$ and represses its expression from another aspect.

\section{Effect of ssc-miR-130b on mRNA abundance of lipid metabolism-related genes in cultured porcine preadipocytes}

PPAR- $\gamma$ is considered as the master regulator of adipogenesis. In the present study, PPAR- $\gamma$ expression

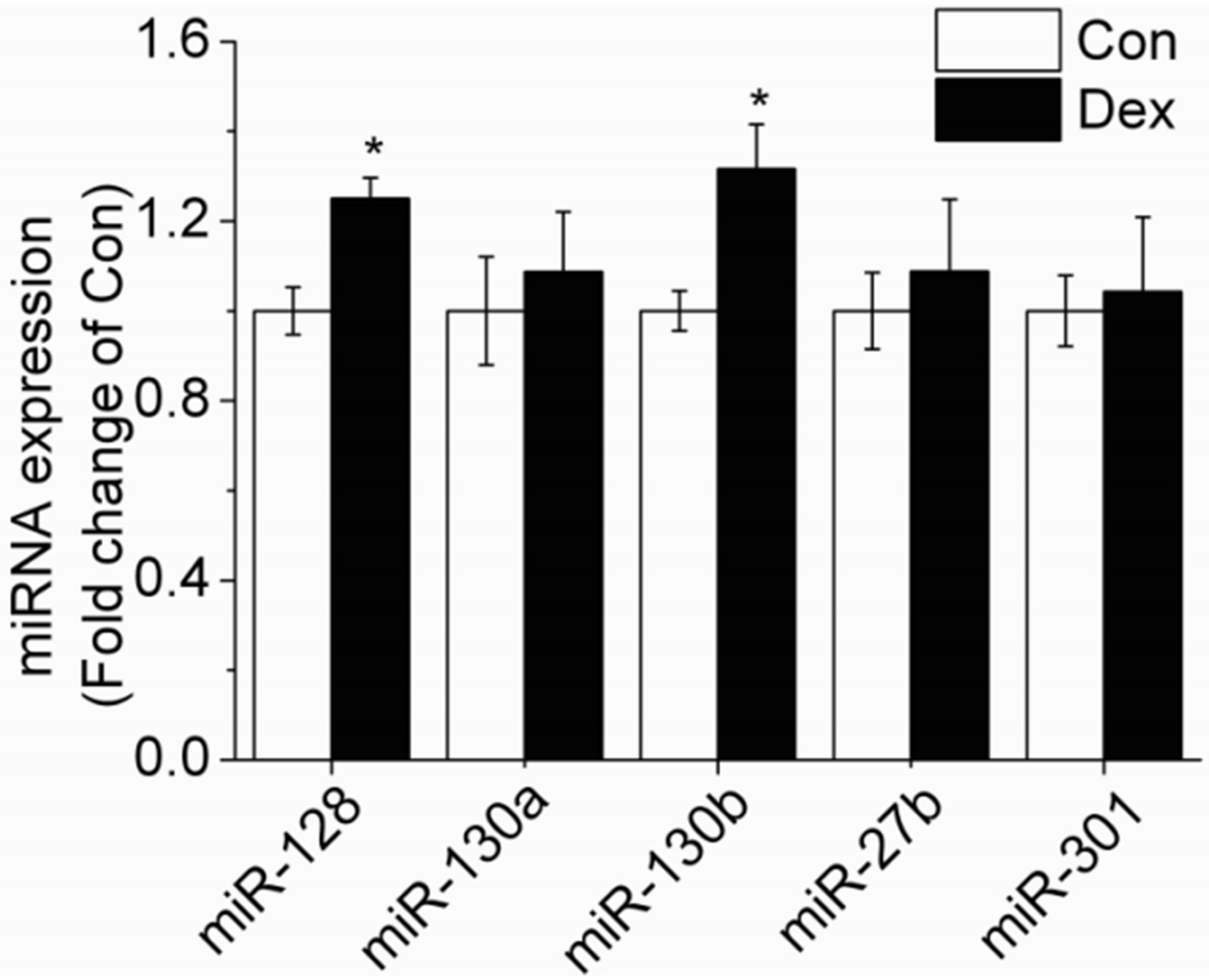

Figure 2: Effect of 10 $0^{-6} \mathrm{M}$ DEX on the expression of miRNAs targeting PPAR- $\gamma$ in porcine preadipocytes. Con: control adipocytes. Dex: $10^{-6} \mathrm{M}$ DEX adipocytes. The values shown represent the means \pm SEM, $\mathrm{n}=6 /$ group. ${ }^{*} P<0.05$ vs. Con cells. 


\section{A. Conserved}

Position 42-48 of PPAR-y 3 ' UTR 5' ...UUUCCCUUCUUCCAGUUGCACUA...3'

$\underline{\text { SSC-miR-130b }}$

3' UACGGGAAAGUAGU-AACGUGAC 5'

B. Highly conserved sites among vertebrates

Ss

Hs

Mm

Ec

Bt

Rn

Gg
PPAR-y 3' UTR $55^{\prime} \quad 30 \cdots \cdots \cdots \cdot 40 \cdots \cdots \cdot 50 \cdots \cdots \cdot 60$

UCCUUCUUCCAAUUGCACUAUUAUUUUG-

-CCUUCUUCCA-UUGCACUAU---U-U--GA

UCCUUCU----AUUGCACUAUUAUUUU--GA

-CCUU-UUCCAAUUGCACUAUUAUUUU--GA

UCCUUCU-CCAAUUGCACUAUUAUUUU--GA

UCCUUCU--C-AUUGCACUAUUAUUUU--GA

---UUCUUC--AUUGCACUAUUUCUUU--GA

miRNA-130b seed $\mathbf{3}^{\prime} \quad$ AACGUGA $\mathbf{5}^{\prime}$

\section{Dual luciferase reporter assays}

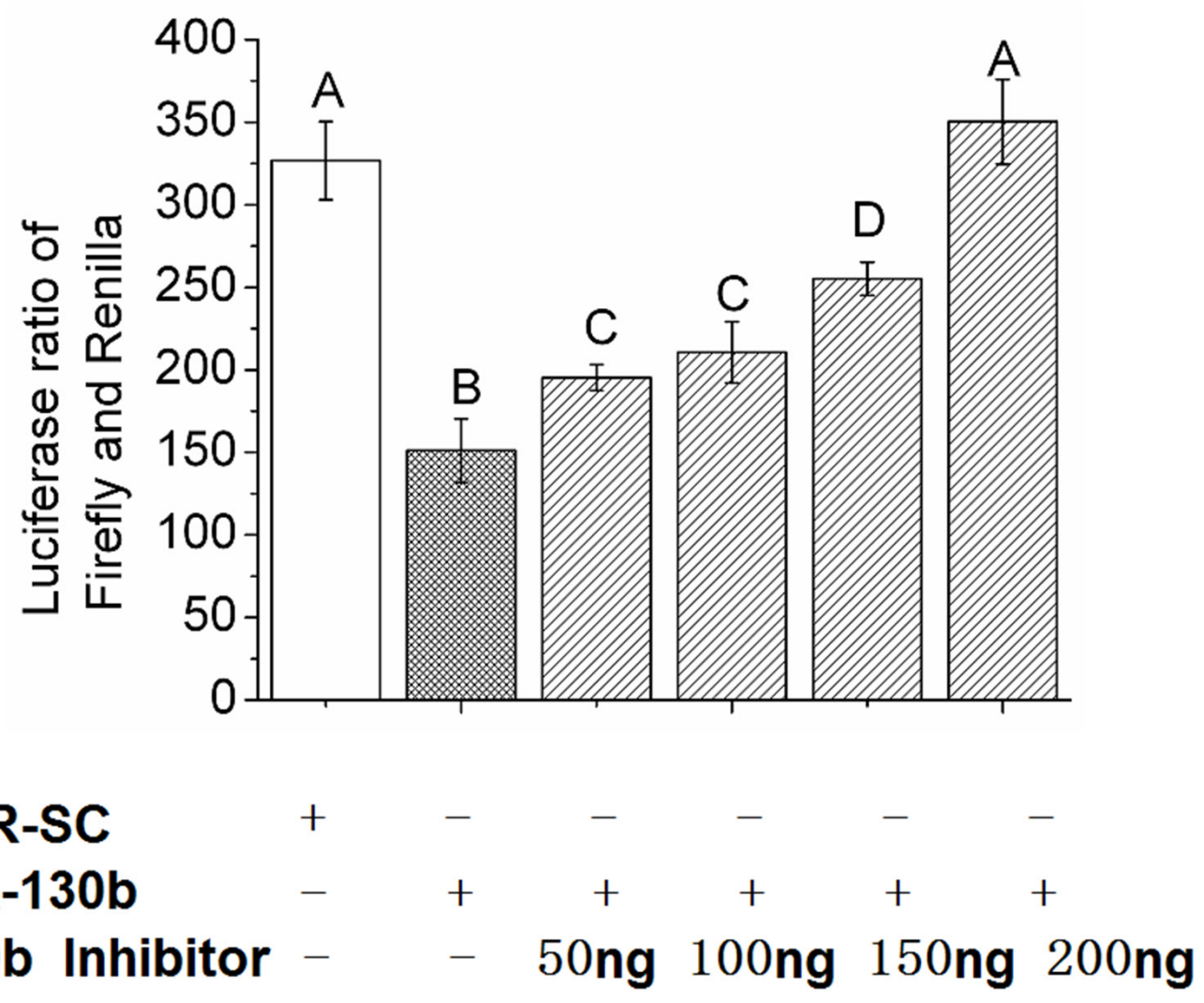

Figure 3: The miR-130b target site in the 3'-UTR of PPAR- $\gamma$ and dual-luciferase activity assay. (A): The predicted, single binding site of miR-130b in the 3'-UTR of pig PPAR- $\gamma$. (B): Conservation of the miR-130b binding region in the PPAR- $\gamma$ 3'-UTR among different species, with the miR-130b seed match highlighted in red (TargetScan). Ss: pig; Hs: human; Mm: mouse; Ec: horse; Bt: cow; Rn: rat; Gg: chicken. (C): Validation of ssc-miR-130b targeting of the PPAR- $\gamma$ 3'-UTR at $24 \mathrm{~h}$ after transfection in HeLa-229 cells. miR-SC: miRNA scrambled control transfected cells. miR-130b: miR-130b transfected cells. miR-130b inhibitor: miR-130b inhibitor transfected cells. The values shown represent the means \pm SEM, $\mathrm{n}=6$ /group. Different letter means significant difference, $P<0.05$. 
was significantly decreased in the miR-130b transfected cells compared with control cells. mRNA expression and phosphorylated protein level of perilipin 1, a structural lipid droplet protein, which plays a key role in regulating lipolysis, were significantly reduced $(P<0.05)$ in miR130b-DEX treated adipocytes when compared with miR-SC-DEX cells (Figure 5A-5B). Furthermore, we found that the mRNA expression of adipose triglyceride lipase (ATGL) and hormone-sensitive lipase (HSL) were significantly increased in miR-130b-DEX cells when compared with miR-SC-DEX cells (Figure 5C). In addition, the activity of lipolytic lipases (including HSL and ATGL) in porcine primary cultured adipocytes was significantly higher $(P<0.05)$ in miR-130b transfected adipocytes than that in control adipocytes (Figure 5D).

In addition, qRT-PCR method was performed to examine the effects of the miR-130b on the mRNA abundance of lipid metabolism-related genes in the porcine primary cultured adipocytes. When compared with miR-SC-DEX cells, mRNA expression and protein levels of acetyl-CoA carboxylase (ACC) and fatty acid synthase (FAS) were significantly reduced $(P<0.05)$ in miR-130b overexpressed cells. Furthermore, expression of 11 betahydroxysteroid dehydrogenase type 1 (11 $\beta$-HSD1) and

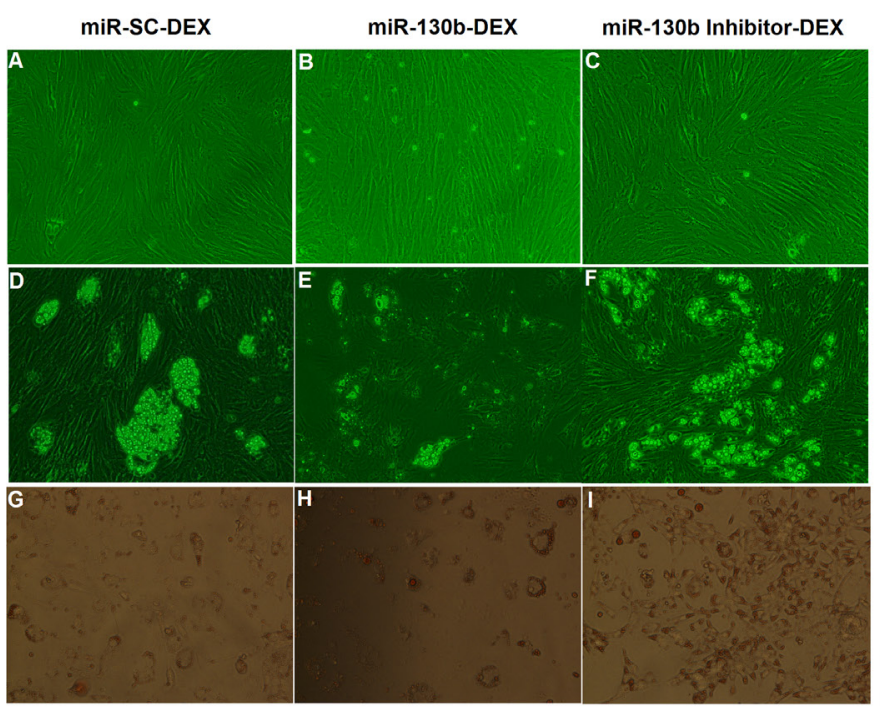

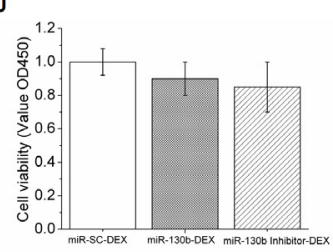

L

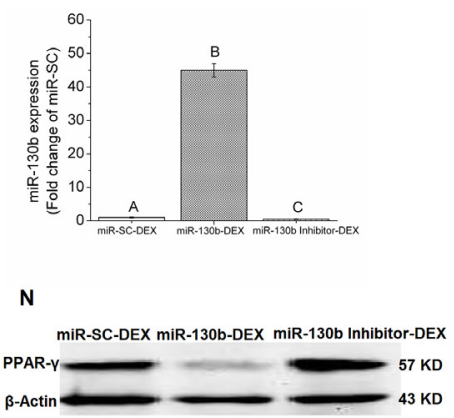

fat mass and obesity associated gene (FTO), were also significantly depressed (Figure 5E-5G).

\section{DISCUSSION}

Higher levels of lipid accumulation can be due to differentiated adipocytes that undergo hypertrophy (increased size) or hyperplasia (increased numbers due to proliferation) [30], therefore, in the present study we detected both the cell viability and the TG content in the adipocytes. Although the cell viability was not affected after treatment with $10^{-6} \mathrm{M}$ dexamethasone for $48 \mathrm{~h}$, the TG content was significantly increased, indicating that $10^{-6}$ $\mathrm{M}$ dexamethasone enhanced lipid accumulation in porcine preadipocytes mainly depends on increased differentiation and lipid synthesis. GCs have been proposed to have both adipogenic and lipolytic actions within adipose tissue, depending on the concentration, duration, and type of GCs investigated, as well as the experimental model utilized [7, 31-33]. Furthermore, as far as we known, the existing studies focusing on the GCs on lipid metabolism are mainly using cell lines and rodent animals as models, we are the first to study the effect of GCs on fat metabolism in primary cultured porcine adipocytes.

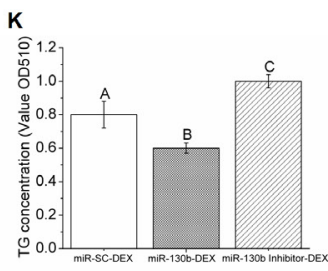

M

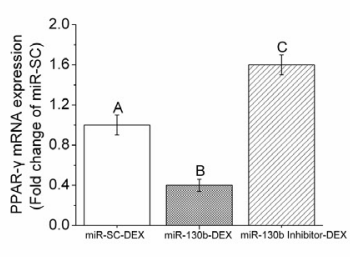

0

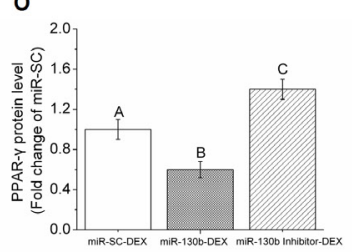

Figure 4: Gain-of-function and loss-of-function of miR-130b in porcine preadipocytes. (A-C): Porcine preadipocytes reached to $85 \%-90 \%$ confluence $(\times 200)$. (D-F): Lipid droplets under the microscope after differentiation for $48 \mathrm{~h}(\times 200)$. (G-I): Oil Red-O staining with adipocytes, the red parts are lipid droplets $(\times 200)$. (J): The cell proliferation and activity. (K): TG quantification. $(\mathbf{L})$ : miR130b expression. (M): PPAR- $\gamma$ mRNA expression. (N): Western blot pictures of PPAR- $\gamma$. (O): PPAR- $\gamma$ protein expression. miR-SC-DEX: cells transfected with miRNA scrambled control for $24 \mathrm{~h}$ before DEX treatment. miR-130b-DEX: cells transfected with miR-130b for 24 $\mathrm{h}$ before DEX treatment. miR-130b-inhibitor-DEX: cells transfected with $100 \mathrm{ng}$ miR-130b inhibitor for $24 \mathrm{~h}$ before DEX treatment. The values shown represent the means \pm SEM, $n=6$ /group. Different letter means significant difference, $P<0.05$. 
Preadipocytes that gradually filled with lipid droplets and differentiated into mature fat cells were regulated by a number of transcription factors, among which PPAR- $\gamma$ serves as the primary regulator of lipid metabolism [34]. In the current study, PPAR- $\gamma$ mRNA and protein expression was significantly increased after treatment with $10^{-6} \mathrm{M}$ dexamethasone for $48 \mathrm{~h}$. This finding is consistent with previous reports demonstrating that PPAR $-\gamma$ overexpression increases adipogenesis [18]. These results showed that $10^{-6} \mathrm{M}$ dexamethasone promotes lipid deposition in primary cultured preadipocytes mainly through up-regulating PPAR- $\gamma$ expression.

Since PPAR- $\gamma$ plays an important role in fat metabolism, it is reasonable to reduce fat deposition by regulating the expression of PPAR- $\gamma$ during the adipocyte differentiation process, eapecially in the exposure of dexamethasone. In recent years, miRNAs were reported to be widely expressed in mammalian adipocytes and played key roles in the process of adipogenesis [35]. More miRNAs need to be digged out to complete the miRNA-
A

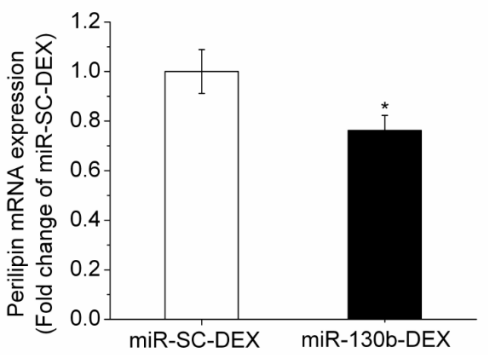

C

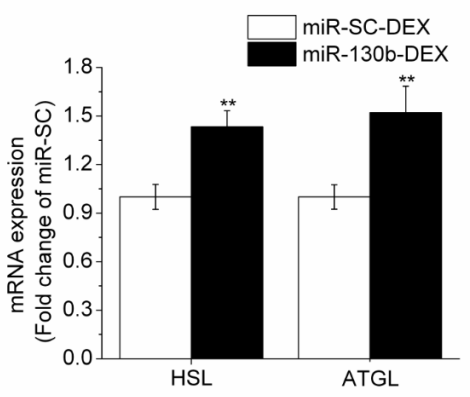

E

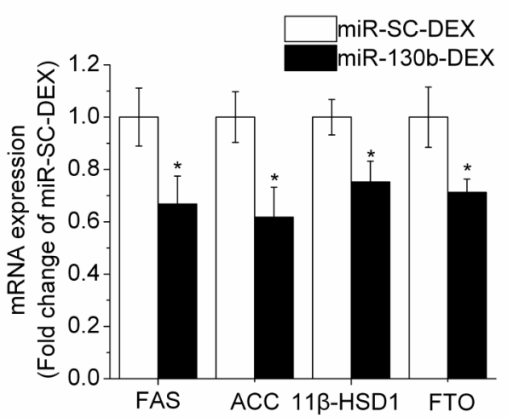

B

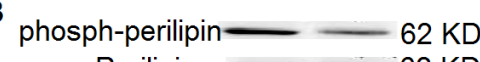

Perilipin $-62 \mathrm{KD}$

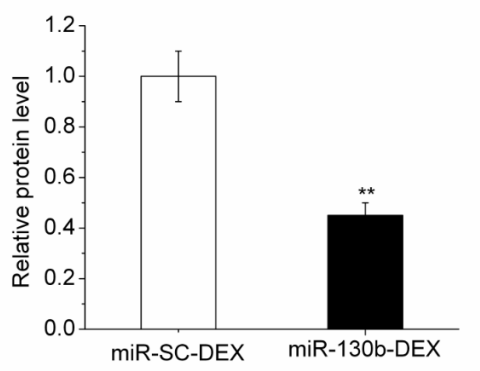

D

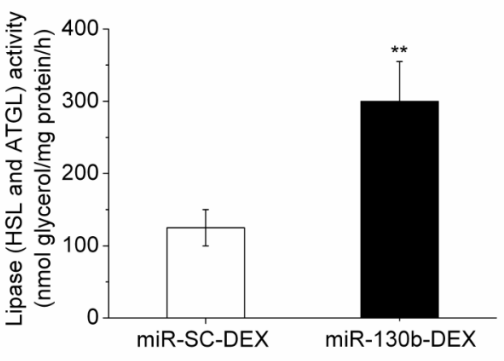

$\mathbf{F}$
miR-SC-DEX miR-130b-DEX

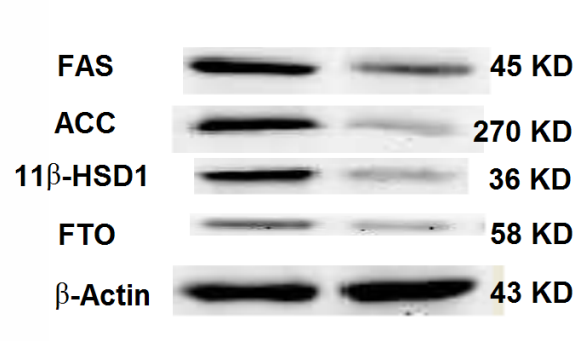

G

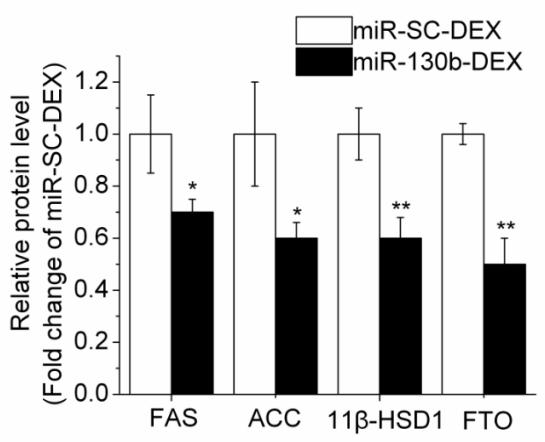

Figure 5: Effect of ssc-miR-130b on mRNA abundance of lipid metabolism-related genes in cultured porcine preadipocytes. (A): Perilipin 1 mRNA expression. (B): Phosphorylated protein level of perilipin 1. (C): mRNA expression of HSL and ATGL. (D): Lipase activity of HSL and ATGL. (E): FAS, ACC, 11ß-HSD1 and FTO mRNA expression. (F-G): FAS, ACC, $11 \beta$-HSD1 and FTO protein levels. miR-SC-DEX: cells transfected with miRNA scrambled control for $24 \mathrm{~h}$ before DEX treatment. miR-130b-DEX: cells transfected with miR-130b for $24 \mathrm{~h}$ before DEX treatment. The values shown represent the means $\pm \mathrm{SEM}, \mathrm{n}=6 /$ group. ${ }^{*} P<0.05 \mathrm{vs}$. miR-SCDEX cells. 
Table 1: Primers used in the present study

\begin{tabular}{|c|c|}
\hline Name & Sequence \\
\hline \multicolumn{2}{|l|}{ Plasmids construction } \\
\hline \multirow{2}{*}{ ssc-miR-130b (MI0013136) } & $\begin{array}{l}\text { F: GATCCGCCTGCCTGACACTCTTTCCCTGTTGCACTACTGTGGGCCACTGGGAAGCAGT } \\
\text { GCAATGATGAAAGGGCATCAGTCAGGCTTTTTTGGAAA }\end{array}$ \\
\hline & $\begin{array}{l}\text { R: AGCTTTTCCAAAAAAGCCTGACTGATGCCCTTTCATCATTGCACTGCTTCCCAGTGGC } \\
\text { CCACAGTAGTGCAACAGGGAAAGAGTGTCAGGCAGGCG }\end{array}$ \\
\hline \multirow{2}{*}{$s s c-m i R-S C$} & $\begin{array}{l}\text { F: GATCCGACTTACAGCCAGTTCCTAGTATAGTGAAGCAGCAGATGGTATACTAGGAAC } \\
\text { TGGCTGTAAGCTTTTTTTGGAAA }\end{array}$ \\
\hline & $\begin{array}{l}\text { R: AGCTTTTCCAAAAAAAGCTTACAGCCAGTTCCTAGTATACCATCTGCTGCTTCACTAT } \\
\text { ACTAGGAACTGGCTGTAAGTCG }\end{array}$ \\
\hline \multicolumn{2}{|l|}{ mRNA expression } \\
\hline \multirow{2}{*}{$P P A R-\gamma\left(\mathrm{NM}_{-} 138711\right)$} & F: GCCCTTCACCACTGTTGATT \\
\hline & R: GAGTTGGAAGGCTCTTCGTG \\
\hline \multirow{2}{*}{ FAS (EF589048) } & F: GTCCTGCTGAAGCCTAACTC \\
\hline & R: TCCTTGGAACCGTCTGTG \\
\hline \multirow{2}{*}{$A C C\left(\mathrm{NM} \_133360.2\right)$} & F: GGCCATCAAGGACTTCAACC \\
\hline & R: ACGATGTAAGCGCCGAACTT \\
\hline \multirow{2}{*}{$11 \beta-H S D 1$ (AF414124) } & F: CCATGCTGAAGCAGAGCAAC \\
\hline & R: AAGAACCCGTCCAGAGCAAA \\
\hline \multirow{2}{*}{ FTO (FJ853994) } & F: GGAGAAAGCCAATATCGACACC \\
\hline & R: TCTGCTCTTCCTGTCCACCTC \\
\hline \multirow{2}{*}{ Perilipin (AY973170) } & F: GCCTGACTTTGCTGGATGG \\
\hline & R: CTTGGTGCTGGTGTAGGTCTTCT \\
\hline \multirow{2}{*}{ HSL (AY686758) } & F: ACCCTCGGCTGTCAACTTCTT \\
\hline & R: TCCTCCTTGGTGCTAATCTCGT \\
\hline \multirow{2}{*}{ ATGL (EF583921) } & F: ACCTGTCCAACCTGCTGC \\
\hline & R: GCCTGTCTGCTCCTTTATCCA \\
\hline \multirow{2}{*}{ PPIA (NM_214353.1) } & F: TCCTCCTTGGTGCTAATCTCGT \\
\hline & R: TGATCTTCTTGCTGGTCTT \\
\hline
\end{tabular}

gene regulatory modules in porcine adipogenesis. In the present study, we identified seven miRNA candidates targeting PPAR- $\gamma$ by bioinformatic analyses. Among the predicated miRNAs, only miR-130b and miR-128 were found to be upregulated in the $10^{-6} \mathrm{M}$ DEX treatment cells, demonstrating that miR-130b and miR-128 may participate in the regulation of PPAR- $\gamma$ expression. In the presnt study, we demonstrated for the first time that miR$130 \mathrm{~b}$ and miR-128 may be able to affect the differentiation process under the treatment with $10^{-6} \mathrm{M}$ DEX. In general, miRNAs mainly act as negative regulators of target genes, however, here we found miR-128 and miR-130b as well as their target gene PPAR- $\gamma$ expression were all significantly increased in $10^{-6} \mathrm{M}$ DEX treated adipocytes, suggesting that the increased expression of PPAR $-\gamma$ may promote the increase of the expression of its potential negative regulators miR-128 and miR-130b by feedback, to maintain self-homeostasis in adipocytes. Indeed, we and others have previously reported that miR-130b was served as a anti-adipogenesis factor in human adipocytes and maternal low protein offspring piglets since miR-130 strongly affected adipocyte differentiation by suppressing PPAR- $\gamma$ expression [27, 28]. Dual-luciferase reporter assays were performed to confirm direct targeting between miR-130b and PPAR- $\gamma$ and the results showed that miR$130 \mathrm{~b}$ overexpression significantly reduced the activity of a luciferase reporter containing the PPAR- $\gamma$ 3'-UTR after cotransfection for $24 \mathrm{~h}$, while cotransfection with miR$130 \mathrm{~b}$ inhibitor could significantly reverse this suppression, indicating that miR-130b can directly recognise and bind to the 3'-UTR of PPAR- $\gamma$ and suppress PPAR- $\gamma$ expression. It is further elaborated from another aspect 
Table 2: PCR primers used for mature miRNAs expression in the present study.

\begin{tabular}{|c|c|}
\hline Name & Sequence \\
\hline \multicolumn{2}{|l|}{ miRNA expression } \\
\hline \multirow[t]{2}{*}{$m i R-130 b$ (MIMAT0013922) } & F: CAGTGCAATGATGAAAGGGCAT \\
\hline & R: TAGAGTGAGTGTAGCGAGCA \\
\hline \multirow[t]{2}{*}{ miR-130a (MIMAT0007758) } & F: CAGTGCAATGTTAAAAGGGCAT \\
\hline & R: TAGAGTGAGTGTAGCGAGCA \\
\hline miR-27b (MIMAT0013889) & F: AGAGCTTAGCTGATTGGTGAACA \\
\hline \multirow[t]{3}{*}{ miR-128 (MIMAT0002157) } & R: TAGAGTGAGTGTAGCGAGCA \\
\hline & F: TCACAGTGAACCGGTCTCTTT \\
\hline & R: TAGAGTGAGTGTAGCGAGCA \\
\hline \multirow[t]{2}{*}{ miR-301 (MIMAT0002138) } & F: CAGTCCAATAGTATTGTCAAAGC \\
\hline & R: TAGAGTGAGTGTAGCGAGCA \\
\hline \multicolumn{2}{|l|}{ Reverse transcription } \\
\hline \multirow[t]{2}{*}{ Exogenous reference gene } & F: GTGACCCACGATGTGTATTCG \\
\hline & R: TAGAGTGAGTGTAGCGAGCA \\
\hline Reverse transcription primer & TAGAGTGAGTGTAGCGAGCACAGCATTAATACGACTCACTATAGG(T)16VN \\
\hline
\end{tabular}

that miR-130b was identified as a central modulator of the effects on PPAR- $\gamma$ inhibition and fat deposition basing on loss- and gain-of-function studies. Although previous study showed that miR-128-3p overexpression was able to effectively inhibit PPAR- $\gamma$ expression in human hepatic stellate cells [36], in the present study, miR-128 did not alter the activity of the luciferase reporter that has PPAR- $\gamma$ 3'-UTR (data not shown). Since one miRNA can have a number of target genes, therefore, other potential targets of miR-128 involved in DEX induced lipid accumulation need to be further studied.

In addition, several lines of evidence demonstrate that perilipin 1, a structural lipid droplet protein, is closely associated with the periphery of lipid storage droplets in cultured adipocytes and plays a key role in regulating lipolysis $[37,38]$. In the basal state, perilipin 1 is located on the lipid droplet surface of an adipocyte along with other lipid droplet-associated proteins, including ATGL, and provides a barrier function between cellular lipases and their substrates $[39,40]$. Upon lipolytic stimulation, phosphorylation of perilipin 1 promotes the release of ATGL coactivator comparative gene identification-58 (CGI-58) [41-43] and recruits HSL to the lipid droplet surface $[44,45]$ to stimulate the hydrolytic activity of ATGL and facilitate the access of HSL to the lipid substrates, respectively. It has been reported that the promoter sequence of the perilipin 1 gene contains a PPAR- $\gamma$ response element binding site and that exposing differentiating 3T3-L1 adipocytes to a PPAR- $\gamma$ agonist significantly augments perilipin $1 \mathrm{mRNA}$ expression [39]. Therefore, the reduced perilipin $1 \mathrm{mRNA}$ expression in the present study may be the consequence of downregulated PPAR- $\gamma$ expression. It has also been proposed that, reduced perilipin 1 may allow more HSL and ATGL to enter into lipid droplets, and enhance lipolysis in target cells, leading to less lipid accumulation [46].

It is widely recognized that each miRNA has multiple target genes that may function through different pathways [47]. Apart from PPAR- $\gamma, 11$ beta-hydroxysteroid dehydrogenase type 1 (11 $\beta$-HSD1) is also predicted to be targeted by miR-130b through bioinformatics methods (data not shown here). Multiple evidence supports that increasing the amount of $11 \beta$-HSD1 in the adipose tissue promotes adipogenesis [48], and $11 \beta$-HSD1 inhibitor prevents human adipogenesis [49]. In the present study, a significant decrease of $11 \beta$-HSD1 mRNA expression was observed after exposure to miR-130b-DEX for $48 \mathrm{~h}$ when compared with miR-SC-DEX treated cells. As a matter of fact, excess GCs promote lipid deposition and the main regulator of intracellular GCs levels is $11 \beta$-HSD1, which converts inactive GCs into bioactive forms [50]. Inhibition of $11 \beta$-HSD1 represents a therapeutic target for treating dexamethasone induced obesity. Inhibition of $11 \beta$-HSD 1 expression may, therefore, be indicative of suppressed adipogenesis in adipocytes exposed to miR-130b. However, until now, only few studies were focused on the regulatory role of miRNAs in $11 \beta$-HSD1 expression, since only miR-561 and -579 are reported to be involved in the 
regulation of 11 $\beta$-HSD1 expression [51]. However, in the present study, whether decreased 11 $\beta$-HSD1 expression was caused by miR-130b overexpression directly or by downregulated PPAR- $\gamma$ indirectly needs to be further studied, because previous studies demonstrated that PPAR- $\gamma$ inactivation was able to reduce $11 \beta-H S D 1$ activity $[52,53]$. Furthermore, expression of FTO gene was also significantly reduced, indicating that lower expression of FTO might be related to suppressed lipid deposition in adipocytes. And this is in accordance with previous reports that downregulated FTO expression is associated with less fat deposition in both adipocytes [54] and adipose tissue [55].

We demonstrated in the present study that expression of FAS and ACC, two key enzymes of de novo lipogenesis, was significantly decreased, suggesting that miR-130b inhibited the de novo lipogenesis of porcine adipocyte. This is in line with the known role of PPAR- $\gamma$ as the master regulator of lipogenesis, driving the expression of numerous of enzymes which are great importances in lipogenesis, including FAS and ACC. In addition, increased expression and the activity of lipolysis enzymes ATGL and HSL suggested activated lipolysis. This is probably contributed by the decreased expression of PPAR- $\gamma$, since previous study has showed that downregulated PPAR- $\gamma$ can stimulate lipolysis, by up-regulating HSL and ATGL expressions [56]. These above results suggested that reduced fat deposition were caused mainly by both repressing adipogenesis and stimulating lipolysis, demonstrating that miR-130b has important roles in regulating fat deposition. However, targeting miR-130b for therapy may have to be tissue specific and will have to be carefully monitored for undesired side-effects, therefore, a complete understanding of the biological functions of miR-130b in an in-vivo model requires further study.

In conclusion, our results showed that $10^{-6} \mathrm{M}$ DEX plays a key role in promoting adipogenesis and fat deposition in primary porcine preadipocytes by increasing PPAR- $\gamma$ expression, furthermore, we demonstrated that this effect can be reversed by prior treatment with miR$130 \mathrm{~b}$, probably by the decrease of PPAR- $\gamma$ and its related gene expression. Further research will be directed at verifying the efficacy of miR-130b in in vivo models. These results provide preliminary evidence showing that miR-130b might be useful for treating DEX caused obesity due to their modulatory effects on fat deposition by affecting adipocyte differentiation.

\section{MATERIALS AND METHODS}

\section{Reagents, cells, and antibodies}

Dulbecco's modified Eagle's media: Nutrient Mixture F-12 (DMEM/F-12) was supplied by Life Technologies Inc. (Carlsbad, CA, USA). Fetal bovine serum (FBS) was obtained from HyClone (Logan, UT,
USA). The human cervix cancer cell line HeLa-229 was purchased from Cell Bank of Chinese Academy of Sciences (Shanghai, China). Antibodies against the following proteins were used: PPAR- $\gamma$ (rabbit polyclonal, 1: 500, AP0686, Bioworld Technology, Inc), ACC (rabbit polyclonal, 1: 500, 21923-1-AP, Proteintech ${ }^{\mathrm{TM}}$ ), FAS (rabbit polyclonal, 1: 500, 13098-1-AP, Proteintech ${ }^{\mathrm{TM}}$ ), 11ß-HSD1 (rabbit polyclonal, 1: 1000, BS5588, Bioworld Technology, Inc), FTO (rabbit polyclonal, 1: 1000, 14386S, Santa Cruz), and $\beta$-actin (mouse monoclonal, 1 : 5000, sc-130656, Santa Cruz). Synthetic RNA molecules and scrambled negative control oligonucleotides were purchased from Invitrogen Life Technologies (Carlsbad, CA, USA). $4 \%$ paraformaldehyde, $20 \%$ glutaraldehyde, pentobarbital sodium, heparin.

\section{Cell culture}

35 day Meishan piglets were killed by exsanguination in a manner approved by the Yangzhou University Institutional Animal Care and Use Committee. Preadipocytes from 6 piglets were isolated according to published protocols $[57,58]$ with the following modifications and pooled together. Subcutaneous adipose tissue was collected from the neck and back of the piglets and rinsed with serum-free DMEM/F-12 medium supplemented with $15 \mathrm{mM} \mathrm{NaHCO}, 100 \mathrm{IU} /$ $\mathrm{mL}$ penicillin (ST488-1, Beyotime, Shanghai, China) and $100 \mathrm{IU} / \mathrm{mL}$ streptomycin (ST488-2, Beyotime, Shanghai, China). The tissue mass was cut with scissors into fine pieces and digested with DMEM/F-12 $+20 \mathrm{~g} / \mathrm{L}$ BSA (GIBCO) (Invitrogen, Carlsbad, CA, USA) $+1 \mathrm{~g} / \mathrm{L}$ type IV collagenase (GIBCO) (Invitrogen, Carlsbad, CA, USA) at $37^{\circ} \mathrm{C}$ in a shaking water bath for approximately $1 \mathrm{~h}$. Then, DMEM/F-12 medium (Invitrogen Life Technologies, Carlsbad, CA, USA) containing 10\% foetal bovine serum (FBS) (Invitrogen Life Technologies, Carlsbad, CA, USA) was added to stop digestion. The solution was filtered through sterile nylon meshes (150 $\mu \mathrm{m}$ pore size, $75 \mu \mathrm{m}$ pore size, $38 \mu \mathrm{m}$ pore size and $23 \mu \mathrm{m}$ pore size) to remove undigested tissue. The filtrate was centrifuged at $1000 \mathrm{rpm}$ for $10 \mathrm{~min}$ to separate the floating adipocyte cells from the pellet of porcine preadipocytes. The preadipocytes were then incubated with erythrocyte lysis buffer $\left(0.154 \mathrm{M} \mathrm{NH}_{4} \mathrm{Cl}, 10 \mathrm{mM} \mathrm{KHCO}\right.$ and $0.1 \mathrm{mM}$ EDTA) at room temperature for $10 \mathrm{~min}$ [59], followed by centrifugation at $800 \mathrm{rpm}$ for $5 \mathrm{~min}$. The preadipocytes pellet was washed with DMEM/F-12, centrifuged, and resuspended in plating medium (20\% FBS, DMEM/F-12). Finally, the preadipocytes were seeded in culture plates at a density of $3 \times 10^{5}$ cells $/ \mathrm{cm}^{2}$. The HeLa-229 cell was cultured in DMEM (Carlsbad, CA, USA) (High glucose) supplement with $10 \%$ fetal bovine serum. Both of the cells were incubated at $37^{\circ} \mathrm{C}$ in a humidified incubator with an atmosphere of $5 \% \mathrm{CO}_{2}$. The medium was changed every second day. 


\section{Preadipocytes grouping and adipogenic differentiation}

In the present study, two experiments were constructed to determine the effect of miR-130b on DEX-induced lipid accumulation and to clarify its potential mechanisms. Cultured porcine preadipocytes were maintained in plating medium until $85 \sim 90 \%$ confluence. In the first experiment, cells were randomly divided into two groups: one is control group (Con), the other one is DEX treatment group (DEX), then to induce differentiation, cells were exposed to medium (without FBS) containing ITS $(5 \mathrm{U} / \mathrm{mL}$ insulin, $5 \mu \mathrm{g} / \mathrm{mL}$ transferrin and $5 \mathrm{ng} / \mathrm{mL}$ selenium, Sigma), $400 \mu \mathrm{M}$ oleic acid (Sigma, St. Louis, MO, USA), and BSA (Invitrogen, Carlsbad, CA, USA) for $48 \mathrm{~h}$, with a ratio of oleic acid to BSA of $6: 1$. In the second experiment, cells were randomly divided into three groups and transfected with different substances at 24 hours before DEX treatment: miR-130b overexpression plasmid group (miR-130b-DEX), miR$130 \mathrm{~b}$ inhibitor group (miR-130b-inhibitor-DEX) and miRNA scrambled control group (miR-SC-DEX), then cells were treated with DEX and differentiation medium for $48 \mathrm{~h}$. All preadipocytes were cultured in DMEM/F-12 plus L-glutamine, penicillin (100 IU/mL), streptomycin $(100 \mathrm{IU} / \mathrm{mL})$ and fungizone $(4 \mu \mathrm{g} / \mathrm{ml})$ (RS0009, Yocon, Beijing, China), at $37^{\circ} \mathrm{C}$ with $5 \% \mathrm{CO}_{2}$.

\section{Cell proliferation detected by cell counting kit-8 (CCK-8)}

For cell proliferation studies, preadipocytes were seeded in 96-well culture plates at a density of $10^{3} /$ well, and then, $100 \mu \mathrm{L}$ DMEM/F-12 medium containing $10 \%$ FBS was added to each well. After $10^{-6} \mathrm{M}$ DEX treatment for $48 \mathrm{~h}$, we test the cell Proliferation with adding 10 $\mu \mathrm{L}$ CCK-8 (Keygentec, Nanjing, China) reagent to each well and then cultured in an incubator for an additional $2 \mathrm{~h}$ at $37^{\circ} \mathrm{C}$ in a humidified, $5 \% \mathrm{CO}_{2}$ atmosphere. The optical density (OD) was read at $450 \mathrm{~nm}$ absorbance on a microplate reader (Synergy ${ }^{\mathrm{TM}}$ HTX, BioTek, Winooski, VT, USA).

\section{TG content determination}

The intracellular TG content was measured according to the method of Oil Red O staining extraction. Preadipocytes were seeded in 24-well culture plates until $85 \sim 90 \%$ confluence, after treatment with $10^{-6} \mathrm{M}$ DEX for $48 \mathrm{~h}$, the old culture medium was removed. Cells were first washed with phosphate buffered saline (PBS) for three times, fixed with $10 \%$ formalin for $5 \mathrm{~min}$ and changed with fixative for $2 \mathrm{~h}$. After fixation, $60 \%$ isopropanol $(1 \mathrm{~mL} / \mathrm{well})$ was added to the plate for 30 s. After removing $60 \%$ isopropanol, Oil Red O working solution (Sunshinebio, Nanjing, China) was added to the plate for $1 \mathrm{~h}(1 \mathrm{~mL} /$ well $)$. And then, Oil Red O working

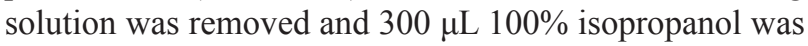
added to the plate to extract Oil Red O. Finally, 100\% isopropanol was collected and the plate was observed with microscope. A wavelength of $510 \mathrm{~nm}$ absorbance value should be determinated with Microplate reader (Synergy BioTek, Vermont, USA), which can reflect the intracellular TG content.

\section{Lipase (including HSL and ATGL) activity assay}

$10^{7}$ adipocytes in $1 \mathrm{~mL}$ of homogenization buffer $\left(0.1 \mathrm{mmol} / \mathrm{L} \mathrm{K}{ }^{+}\right.$-PBS containing $1 \mathrm{mmol} / \mathrm{L} \mathrm{MgCl} 2,1$ $\mathrm{mmol} / \mathrm{L}$ DTT and $1 \mathrm{mmol} / \mathrm{L}$ EDTA) was homogenized in ice for $30 \mathrm{~min}$, and then centrifuged at $12,000 \times \mathrm{g}$ at $4^{\circ} \mathrm{C}$ for $10 \mathrm{~min}$. The protein concentration of supernatants was measured with the BCA Protein Assay Kit (Pierce Chemical Corp., Rockford, USA). Triolein without glycerin was used as substrate which can be hydrolysed to glycerol by the two enzymes, HSL and ATGL. The supernatant together with prepared triolein were incubated for $1 \mathrm{~h}$ at $37^{\circ} \mathrm{C}$. The lipases in supernatant activate the lypolytic degradation of the triolein emulsion. The released glycerol was determined using a commercial kit (Applygen, China). To fit the activities of the enzymes to the linear range of standard curves constructed with pure enzymes, all samples were measured in duplicate at appropriate dilutions. The activity of lipases is expressed as nanomoles released glycerol per milligram protein per hour.

\section{RNA extraction and real-time PCR}

Total RNA was extracted from homogenised adipose cells using the TRIzol Total RNA Kit (Invitrogen Life Technologies, Carlsbad, CA, USA) according to the manufacturer's instructions and reverse-transcribed with the PrimeScript First Strand cDNA Synthesis kit (no. D6110A, Takara). Two microliters of diluted cDNA (1: 20) were used in each real-time PCR assay by Mx3000P (Stratagene). Peptidylprolyl isomerase A (PPIA) was chosen as a housekeeping gene after comparing with GAPDH and $\beta$-actin through NormFinder analysis, because it is expressed in abundance comparable to the genes of interest and its expression was not affected by the treatment. Relative mRNA levels were determined by comparing the PCR cycle threshold between control and $10^{-6} \mathrm{M}$ DEX groups after normalizing for PPIA. Data are shown as fold change compared to the control group. All primers were synthesized by Genewiz, Inc (Suzhou, China) and listed in Table 1.

\section{Bioinformatics method}

The miRNA targets predicted by computer-aided algorithms were obtained from miRGen (http://www.diana. 
pcbi.upenn.edu/miRGen.html) [47], TargetScan (http://www. targetscan.org/vert_42/) [60], PicTar (http://pictar.org/) [61], and miRanda (http://www.microrna.org/microrna/).

\section{miRNA real-time PCR quantification}

RT-PCR analysis of miRNA expression was performed in an Mx3000P (Stratagene, Santa Clara, CA, USA) with specific primers (Table 2). Briefly, total RNA was extracted from adipocytes using TRIZOL Reagent (Invitrogen Life Technologies, Carlsbad, CA, USA) and subsequently purified with the RNase-Free DNase Set (Promega, Madison, USA) according to the manufacturer's instructions. The treated total RNA (4 $\mu \mathrm{g})$ was polyadenylated by poly(A) polymerase (PAP) at $37^{\circ} \mathrm{C}$ for 1 $\mathrm{h}$ in a $20 \mu \mathrm{L}$ reaction mixture following the manufacturer's directions for the Poly(A) Tailing Kit (AM1350, Ambion, USA) [61]. The tailing reactions contained $4 \mu \mathrm{g}$ of RNA samples $(1 \mu \mathrm{g} / \mu \mathrm{L}), 4 \mu \mathrm{L}$ of $5 \times$ E-PAP buffer, $2 \mu \mathrm{L}$ of 25 $\mathrm{mM} \mathrm{MnCl}, 2 \mu \mathrm{L}$ of $10 \mathrm{mM}$ ATP, $0.8 \mu \mathrm{L}$ of E-PAP, and the external controls (E1, E2 and E5) at 0.2 pmol each, this reaction solution was brought up to a $20 \mu \mathrm{L}$ final volume with nuclease-free water. After phenol-chloroform extraction and ethanol precipitation, the RNAs were dissolved in DEPC-treated water and cDNAs were synthesised from tailing RNAs using a gene-specific oligo dT-adapter primer (1 $\mu \mathrm{g} / \mu \mathrm{L})$. Reverse transcriptase reactions contained 2 $\mu \mathrm{g}$ poly-A tailed RNAs and $1 \mu \mathrm{L}$ of oligo dT-adapter (1 $\mu \mathrm{g} / \mu \mathrm{L})$. The $10 \mu \mathrm{L}$ reactions were incubated for $5 \mathrm{~min}$ at $70^{\circ} \mathrm{C}$ (RT1). The RT2 reactions consisted of the entire RT1 reactions, mixed with $5 \mu \mathrm{L}$ M-MLV $5 \times$ buffer (containing $250 \mathrm{mM}$ pH 8.3 Tris- $\mathrm{HCl}, 15 \mathrm{mM} \mathrm{MgCl}, 375 \mathrm{mM} \mathrm{KCl}$ and $50 \mathrm{mM}$ DTT), $1.25 \mu \mathrm{L} 10 \mathrm{mM}$ dNTP, $1 \mu \mathrm{L}$ M-MLV RNase $(200 \mathrm{U} / \mu \mathrm{L}), 0.5 \mu \mathrm{L}$ RNase inhibitor $(40 \mathrm{U} / \mu \mathrm{L})$. The $25 \mu \mathrm{L}$ reactions were incubated at $42^{\circ} \mathrm{C}$ for $1 \mathrm{~h}$ and then at $95^{\circ} \mathrm{C}$ for $5 \mathrm{~min}$. The $25 \mu \mathrm{L}$ PCR reactions included $2 \mu \mathrm{L}$ RT product, $2 \mu \mathrm{L}$ primers (Table 2 ), $8.5 \mu \mathrm{L}$ sterile $3 \mathrm{~d} \mathrm{H}_{2} \mathrm{O}$, and 12.5 $\mu \mathrm{L}$ SYBR Premix Ex Taq TM (TaKaRa, Tokyo, Japan). The reactions were incubated in a 96-well optical plate at $95^{\circ} \mathrm{C}$ for $5 \mathrm{~min}$, followed by 28 cycles at $95^{\circ} \mathrm{C}$ for 30 $\mathrm{s}$ and $66^{\circ} \mathrm{C}$ for $30 \mathrm{~s}$. The PCR reactions run on an Mx 3000P (Agilent Technologies Stratagene, Santa Clara, CA, USA) and analysed using the Mx 3000P System SDS software.

E5 small nuclear RNA was used as an external control to normalise RNA input. The $\mathrm{Ct}$ value is defined as the fractional cycle number at which the fluorescence passes the fixed threshold. The fold change was calculated using the $2^{-\Delta \Delta C t}$ method, presented as the fold-expression change in DEX-treated adipocytes relative to their corresponding control adipocytes after normalisation to the endogenous control. All experiments were performed in triplicate.

\section{Determination of protein expression}

One bottle $\left(25 \mathrm{~cm}^{2}\right)$ of frozen adipocytes was extracted in $1 \mathrm{ml}$ lysis buffer containing $100 \mathrm{mM} \mathrm{NaCl}, 2$
mM EDTA, 5\% SDS, 0.1 mM Na $\mathrm{VO}_{3}$, $50 \mathrm{mM} \mathrm{NaF}, 1 \mathrm{mM}$ benzamidine, $100 \mu \mathrm{M}$ AEBSF, $10 \mu \mathrm{g} / \mathrm{ml}$ aprotinin and 50 $\mathrm{mM}$ HEPES ( $\mathrm{pH}$ 7.4). The protein content was measured with the BCA Protein Assay Kit (Pierce biotechnology, Rockford, Illinois, USA, 23227). Forty micrograms of protein extract was mixed with loading buffer and denatured by boiling for $5 \mathrm{~min}$ before being loaded on a $10 \%$ SDS-polyacrylamide gel. After electrophoresis, the proteins were transferred to nitrocellulose membranes and blocked with 3\% BSA in Tween-Tris-buffered saline for $90 \mathrm{~min}$ at room temperature. After repeated washing with Tween-Tris-buffered saline, the membranes were incubated with the appropriate antibodies. Western blot analysis for detecting PPAR- $\gamma$, FAS, ACC, $11 \beta$-HSD 1 and FTO were performed with different polyclonal antibodies. An antibody against $\beta$-actin (Abcam, Cambridge, UK) was used as an internal standard at a 1: 5,000 dilution. Goat anti-rabbit IgG peroxidase-conjugated secondary antibodies (Bioworld Technology, Minneapolis, USA) were used at a dilution of 1: 10,000. Finally, the bands were visualized by enhanced chemiluminescence with the LumiGlo substrate (Super Signal West Pico Trial Kit, Pierce, Rockford, IL, U.S.A.) and captured by VersaDoc 4000MP system (Bio-Rad, Hercules, CA, U.S.A.) to calculate the value of band density using Quantity One software (Bio-Rad) automatically. The protein content was presented as the fold change relative to the control. The experiments were performed in triplicate.

\section{Plasmid construction}

A 387 bp fragment of the PPAR- $\gamma$ 3'-UTR, which contains one predicted conserved target site of miR-130b, was amplified by PCR using the primers 5'-GCTGCTGCAAGTAATAAAG-3' and 5'-TAAAGGAAGGAAGAGGGAG-3'. The 387 bp fragment, which contains a motif for miR-130b that is broadly conserved in vertebrates (www.targetscan.org), was subcloned into the luciferase reporter pGL3-Control using XbaI (Invitrogen Life Technologies, Carlsbad, CA, USA). These constructs were named pGL3-control/ PPAR- $\gamma$.

Approximately 89 bp precursors of miR-130b and miR-SC were synthesized by Invitrogen Life Technology (Carlsbad, CA, USA). The synthesis was based on the sequence information from pig miRNA precursors (www. mirbase.org) and the requirements for pSilencer 3.1-H1 siRNA expression vector (Ambion, Austin, TX, USA). Precursors of miR-130b and miR-SC were annealed using annealing buffer $(5 \times)$, miRNA precursor upstream sequence $(50 \mu \mathrm{mol} / \mathrm{L})$ and downstream sequence (50 $\mu \mathrm{mol} / \mathrm{L}$ ) (Table 1). The $50 \mu \mathrm{L}$ solutions were incubated in 96-well optical plates at $95^{\circ} \mathrm{C}$ for $2 \mathrm{~min}$, and subjected to touchdown PCR. During this procedure the temperature was decreased $0.1^{\circ} \mathrm{C}$ every $8 \mathrm{~s}$ until it reached $25^{\circ} \mathrm{C}$. The PCR products were subcloned into pSilencer 3.1- 
H1 siRNA expression vector using BamHI and HindIII restricted endonuclease (Invitrogen Life Technologies, Carlsbad, CA, USA).

\section{DNA transfection}

Approximately $3 \times 10^{4} / \mathrm{cm}^{3} \mathrm{HeLa}$ cells were seeded and cultured in $25 \mathrm{~cm}^{2}$ cell culture bottles. When the cells reached $90-95 \%$ confluence, they were cotransfected with 100 ng of pGL3-control/ PPAR- $\gamma$ 3'-UTR fluorescent luciferase reporter plasmid, $10 \mathrm{ng}$ of pRL-TK plasmid (used to normalise for transformation efficiency), or 100 ng of pSilence 3.1 H1-neo miR-130b with Lipofectamine 2000 (Invitrogen Life Technologies, Carlsbad, CA, USA) according to the manufacturer's instructions. Negative controls were cotransfected with $100 \mathrm{ng}$ of miR-SC, $100 \mathrm{ng}$ of pGL3-control/ PPAR- $\gamma$ 3'-UTR fluorescent luciferase reporter plasmid and $10 \mathrm{ng}$ of pRL-TK plasmid. At the same time, different concentrations of miR-130b inhibitor (Invitrogen Life Technologies, Carlsbad, CA, USA) were added to the medium of the cotransfected cells. The transfected HeLa cells were incubated at 5\% $\mathrm{CO}_{2}$ and $37^{\circ} \mathrm{C}$ for $24 \mathrm{~h}$.

\section{Dual luciferase activity assay}

Twenty-four hours after transfection, firefly and renilla luciferase activities were measured using a DualLuciferase Assay Kit (Promega, Madison, USA) with a plate reader (Perkin Elmer, Waltham, MA, USA). The renilla and firefly luciferase signals were detected using the Veritas Microplate Luminometer (Turner Biosystems, Sunnyvale, CA, USA). The firefly luciferase signal was normalized to the renilla luciferase signal. The normalized firefly luciferase activity was compared between miR-130b and miR-SC cells. The results were expressed as relative activity. Each target construct was tested in triplicate, and the assay was repeated to confirm the results.

\section{Statistical analysis}

All data are presented as the mean \pm SEM. Statistical analyses were carried out with Statistical Program for Social Sciences (SPSS) software 20.0 for Windows (SPSS Inc., Chicago, IL, USA). The differences were tested with a one-way ANOVA. A $P$-value of less than 0.05 was considered significant.

\section{Abbreviations}

ACC, acetyl coenzyme A carboxylase; ATGL, adipose triglyceride lipase; DEX, dexamethasone; DMEM/F-12, dulbecco's modified eagle's media: nutrient mixture F-12; FAS, fatty acid synthetase; FBS, fetal bovine serum; FTO, fat mass and obesity associated gene; HSL, hormone-sensitive lipase; Mir, microRNA; PPAR- $\gamma$, peroxisome proliferator-activated receptor- $\gamma$; RT-PCR, quantitative real-time polymerse chain reaction; SCD1, stearoyl-coenzyme A desaturase 1; SPSS, statistical program for social sciences; TG, triglycerides; 3'-UTR, 3 '-untranslated region; $11 \beta$-HSD1, $11 \beta$ hydroxysteroid dehydrogenase type 1 .

\section{Author contributions}

$\mathrm{YC}$ and $\mathrm{XD}$ performed the experiments, analyzed and interpreted the results, and drafted the manuscript. TZ contributed ideas for experimental design. HX and SP contributed to experimental concepts and design, provided scientific direction, analyzed and interpreted the results, and finalized the manuscript. All authors read and approved the final manuscript.

\section{CONFLICTS OF INTEREST}

The authors report no conflicts of interest. The authors alone are responsible for the content and writing of the paper. Each author certifies that he or she has no commercial associations (e.g. consultancies, stock ownership, equity interest, patent/licensing arrangements) that might pose a conflicts of interest in connection with the submitted article.

\section{FUNDING}

This work was supported by the National Natural Science Foundation of China (No.31501923), the Natural Science Foundation of Jiangsu Province (BK20150443), China Postdoctoral Science Foundation Funded Project and Postdoctoral Science Foundation Funded Project of Jiangsu Province (No.137070149), the Priority Academic Program Development of Jiangsu Higher Education Institutions (PAPD).

\section{REFERENCES}

1. Hruby A, Hu FB. The Epidemiology of Obesity: A Big Picture. PharmacoEconomics. 2015; 33:673-689.

2. Carmienke S, Freitag MH, Pischon T, Schlattmann P, Fankhaenel T, Goebel H, Gensichen J. General and abdominal obesity parameters and their combination in relation to mortality: a systematic review and metaregression analysis. European journal of clinical nutrition. 2013; 67:573-585.

3. Ruiz JR, Labayen I, Ortega FB. Letter to the Editor: Metabolically Healthy (and Fit?) Obesity. The Journal of clinical endocrinology and metabolism. 2017; 102:1084-1085.

4. Vodicka P, Smetana K Jr, Dvorankova B, Emerick T, Xu YZ, Ourednik J, Ourednik V, Motlik J.The miniature pig as an animal model in biomedical research. Annals of the New York Academy of Sciences. 2005; 1049:161-171. 
5. Bendixen E, Danielsen M, Larsen K, Bendixen C. Advances in porcine genomics and proteomics--a toolbox for developing the pig as a model organism for molecular biomedical research. Briefings in functional genomics. 2010; 9:208-219.

6. Schuster DP. Changes in physiology with increasing fat mass. Seminars in pediatric surgery. 2009; 18:126-135.

7. Andrews RC, Herlihy O, Livingstone DE, Andrew R, Walker BR. Abnormal cortisol metabolism and tissue sensitivity to cortisol in patients with glucose intolerance. The Journal of clinical endocrinology and metabolism. 2002; 87:5587-5593.

8. Peckett AJ, Wright DC, Riddell MC. The effects of glucocorticoids on adipose tissue lipid metabolism. Metabolism: clinical and experimental. 2011; 60:1500-1510.

9. Djurhuus $\mathrm{CB}$, Gravholt $\mathrm{CH}$, Nielsen $\mathrm{S}$, Mengel A, Christiansen JS, Schmitz OE, Moller N. Effects of cortisol on lipolysis and regional interstitial glycerol levels in humans. American journal of physiology endocrinology and metabolism. 2002; 283:E172-177.

10. Krsek M, Rosicka M, Nedvidkova J, Kvasnickova H, Hana V, Marek J, Haluzik M, Lai EW, Pacak K. Increased lipolysis of subcutaneous abdominal adipose tissue and altered noradrenergic activity in patients with Cushing's syndrome: an in-vivo microdialysis study. Physiological research. 2006; 55:421-428.

11. Wiper-Bergeron N, Wu D, Pope L, Schild-Poulter C, Hache RJ. Stimulation of preadipocyte differentiation by steroid through targeting of an HDAC1 complex. The EMBO journal. 2003; 22:2135-2145.

12. Caprio M, Feve B, Claes A, Viengchareun S, Lombes M, Zennaro MC. Pivotal role of the mineralocorticoid receptor in corticosteroid-induced adipogenesis. FASEB journal. 2007; 21:2185-2194.

13. Sun K, Kusminski CM, Scherer PE. Adipose tissue remodeling and obesity. The Journal of clinical investigation. 2011; 121:2094-2101.

14. Jo J, Gavrilova O, Pack S, Jou W, Mullen S, Sumner AE, Cushman SW, Periwal V. Hypertrophy and/or Hyperplasia: Dynamics of Adipose Tissue Growth. PLoS computational biology. 2009; 5:e1000324.

15. Lefterova MI, Lazar MA. New developments in adipogenesis. Trends in endocrinology and metabolism: TEM. 2009; 20:107-114.

16. Baek K, Cho JY, Hwang HR, Kwon A, Lee HL, Park HJ, Qadir AS, Ryoo HM, Woo KM, Baek JH. Myeloid Elf-1like factor stimulates adipogenic differentiation through the induction of peroxisome proliferator-activated receptor gamma expression in bone marrow. Journal of cellular physiology. 2012; 227:3603-3612.

17. Nakanishi N, Nakagawa $\mathrm{Y}$, Tokushige N, Aoki N, Matsuzaka T, Ishii K, Yahagi N, Kobayashi K, Yatoh S, Takahashi A, Suzuki H, Urayama O, Yamada N, Shimano H. The up-regulation of microRNA-335 is associated with lipid metabolism in liver and white adipose tissue of genetically obese mice. Biochemical and biophysical research communications. 2009; 385:492-496.

18. Barak Y, Nelson MC, Ong ES, Jones YZ, Ruiz-Lozano P, Chien KR, Koder A, Evans RM. PPAR gamma is required for placental, cardiac, and adipose tissue development. Molecular cell. 1999; 4:585-595.

19. Cruz KJ, de Oliveira AR, Morais JB, Severo JS, Marreiro $\mathrm{Ph}$ DD. Role of microRNAs on adipogenesis, chronic low-grade inflammation, and insulin resistance in obesity. Nutrition (Burbank, Los Angeles County, Calif). 2017; 35:28-35.

20. Silverman BR, Shi J. Alterations of epigenetic regulators in pancreatic cancer and their clinical implications. International journal of molecular sciences. 2016; 17.

21. Chen L, Hou J, Ye L, Chen Y, Cui J, Tian W, Li C, Liu L. MicroRNA-143 regulates adipogenesis by modulating the MAP2K5-ERK5 signaling. Scientific reports. 2014; 4:3819.

22. Mori M, Nakagami H, Rodriguez-Araujo G, Nimura K, Kaneda Y. Essential role for miR-196a in brown adipogenesis of white fat progenitor cells. PLoS biology. 2012; 10:e1001314.

23. Karbiener M, Pisani DF, Frontini A, Oberreiter LM, Lang E, Vegiopoulos A, Mossenbock K, Bernhardt GA, Mayr T, Hildner F, Grillari J, Ailhaud G, Herzig S, et al. MicroRNA-26 family is required for human adipogenesis and drives characteristics of brown adipocytes. Stem cells. 2014; 32:1578-1590.

24. Sun L, Trajkovski M. MiR-27 orchestrates the transcriptional regulation of brown adipogenesis. Metabolism: clinical and experimental. 2014; 63:272-282.

25. Chen Y, Siegel F, Kipschull S, Haas B, Frohlich H, Meister G, Pfeifer A. miR-155 regulates differentiation of brown and beige adipocytes via a bistable circuit. Nature communications. 2013; 4:1769.

26. Miki H, Yamauchi T, Suzuki R, Komeda K, Tsuchida A, Kubota N, Terauchi Y, Kamon J, Kaburagi Y, Matsui J, Akanuma Y, Nagai R, Kimura S, et al. Essential role of insulin receptor substrate 1 (IRS-1) and IRS-2 in adipocyte differentiation. Molecular and cellular biology. 2001; 21:2521-2532.

27. Lee EK, Lee MJ, Abdelmohsen K, Kim W, Kim MM, Srikantan S, Martindale JL, Hutchison ER, Kim HH, Marasa BS, Selimyan R, Egan JM, Smith SR, et al. miR130 suppresses adipogenesis by inhibiting peroxisome proliferator-activated receptor gamma expression. Molecular and cellular biology. 2011; 31:626-638.

28. Pan S, Zheng Y, Zhao R, Yang X. MicroRNA-130b and microRNA-374b mediate the effect of maternal dietary protein on offspring lipid metabolism in Meishan pigs. The British journal of nutrition. 2013, 109:1731-1738.

29. Tessel MA, Benham AL, Krett NL, Rosen ST, Gunaratne $\mathrm{PH}$. Role for microRNAs in regulating glucocorticoid 
response and resistance in multiple myeloma. Hormones \& cancer. 2011; 2:182-189.

30. Rosen ED, MacDougald OA. Adipocyte differentiation from the inside out. Nature reviews Molecular cell biology. 2006; 7:885-896.

31. Kershaw EE, Hamm JK, Verhagen LA, Peroni O, Katic M, Flier JS. Adipose triglyceride lipase: function, regulation by insulin, and comparison with adiponutrin. Diabetes. 2006; 55:148-157.

32. Masuzaki H, Paterson J, Shinyama H, Morton NM, Mullins JJ, Seckl JR, Flier JS. A transgenic model of visceral obesity and the metabolic syndrome. Science (New York, NY). 2001; 294:2166-2170.

33. Ottosson M, Lonnroth P, Bjorntorp P, Eden S. Effects of cortisol and growth hormone on lipolysis in human adipose tissue. The Journal of clinical endocrinology and metabolism. 2000; 85:799-803.

34. Poulos SP, Dodson MV, Culver MF, Hausman GJ. The increasingly complex regulation of adipocyte differentiation. Experimental biology and medicine (Maywood, NJ). 2016; 241:449-456.

35. McGregor RA, Choi MS. microRNAs in the regulation of adipogenesis and obesity. Current molecular medicine. 2011; 11:304-316.

36. Povero D, Panera N, Eguchi A, Johnson CD, Papouchado BG, de Araujo Horcel L, Pinatel EM, Alisi A, Nobili $\mathrm{V}$, Feldstein AE. Lipid-induced hepatocyte-derived extracellular vesicles regulate hepatic stellate cell via microRNAs targeting PPAR-gamma. Cellular and molecular gastroenterology and hepatology. 2015; 1:646663 e644.

37. Greenberg AS, Egan JJ, Wek SA, Garty NB, BlanchetteMackie EJ, Londos C. Perilipin, a major hormonally regulated adipocyte-specific phosphoprotein associated with the periphery of lipid storage droplets. The Journal of biological chemistry. 1991; 266:11341-11346.

38. Brasaemle DL. Thematic review series: adipocyte biology. The perilipin family of structural lipid droplet proteins: stabilization of lipid droplets and control of lipolysis. Journal of lipid research. 2007; 48:2547-2559.

39. Arimura N, Horiba T, Imagawa M, Shimizu M, Sato R. The peroxisome proliferator-activated receptor gamma regulates expression of the perilipin gene in adipocytes. The Journal of biological chemistry. 2004; 279:10070-10076.

40. Tansey JT, Sztalryd C, Gruia-Gray J, Roush DL, Zee JV, Gavrilova O, Reitman ML, Deng CX, Li C, Kimmel AR, Londos C. Perilipin ablation results in a lean mouse with aberrant adipocyte lipolysis, enhanced leptin production, and resistance to diet-induced obesity. Proceedings of the National Academy of Sciences of the United States of America. 2001; 98:6494-6499.

41. Subramanian V, Rothenberg A, Gomez C, Cohen AW, Garcia A, Bhattacharyya S, Shapiro L, Dolios G, Wang R, Lisanti MP, Brasaemle DL. Perilipin A mediates the reversible binding of CGI-58 to lipid droplets in 3T3-L1 adipocytes. The Journal of biological chemistry. 2004; 279:42062-42071.

42. Lass A, Zimmermann R, Haemmerle G, Riederer M, Schoiswohl G, Schweiger M, Kienesberger P, Strauss JG, Gorkiewicz G, Zechner R. Adipose triglyceride lipasemediated lipolysis of cellular fat stores is activated by CGI58 and defective in Chanarin-Dorfman Syndrome. Cell metabolism. 2006; 3:309-319.

43. Miyoshi H, Perfield JW 2nd, Souza SC, Shen WJ, Zhang HH, Stancheva ZS, Kraemer FB, Obin MS, Greenberg AS. Control of adipose triglyceride lipase action by serine 517 of perilipin A globally regulates protein kinase A-stimulated lipolysis in adipocytes. The Journal of biological chemistry. 2007; 282:996-1002.

44. Su CL, Sztalryd C, Contreras JA, Holm C, Kimmel AR, Londos C. Mutational analysis of the hormone-sensitive lipase translocation reaction in adipocytes. The Journal of biological chemistry. 2003; 278:43615-43619.

45. Miyoshi H, Souza SC, Zhang HH, Strissel KJ, Christoffolete MA, Kovsan J, Rudich A, Kraemer FB, Bianco AC, Obin MS Greenberg AS. Perilipin promotes hormone-sensitive lipase-mediated adipocyte lipolysis via phosphorylationdependent and -independent mechanisms. The Journal of biological chemistry. 2006; 281:15837-15844.

46. Sztalryd C, Brasaemle D.: The perilipin family of lipid droplet proteins: Gatekeepers of intracellular lipolysis. Biochimica et biophysica acta. 2017.

47. Krek A, Grun D, Poy MN, Wolf R, Rosenberg L, Epstein EJ, MacMenamin P, da Piedade I, Gunsalus KC, Stoffel M, Rajewsky N. Combinatorial microRNA target predictions. Nature genetics. 2005; 37:495-500.

48. Wang J, Sun B, Hou M, Pan X, Li X. The environmental obesogen bisphenol A promotes adipogenesis by increasing the amount of 11 beta-hydroxysteroid dehydrogenase type 1 in the adipose tissue of children. International journal of obesity. 2013; 37:999-1005.

49. Bujalska IJ, Gathercole LL, Tomlinson JW, Darimont C, Ermolieff J, Fanjul AN, Rejto PA, Stewart PM. A novel selective 11beta-hydroxysteroid dehydrogenase type 1 inhibitor prevents human adipogenesis. The Journal of endocrinology. 2008; 197:297-307.

50. Tagawa N, Kubota S, Kobayashi Y, Kato I. Genistein inhibits glucocorticoid amplification in adipose tissue by suppression of 11 beta-hydroxysteroid dehydrogenase type 1. Steroids. 2015; 93:77-86.

51. Han Y, Staab-Weijnitz CA, Xiong G, Maser E. Identification of microRNAs as a potential novel regulatory mechanism in HSD11B1 expression. The Journal of steroid biochemistry and molecular biology. 2013; 133:129-139.

52. Chinetti-Gbaguidi G, Bouhlel MA, Copin C, Duhem C, Derudas B, Neve B, Noel B, Eeckhoute J, Lefebvre P, Seckl JR, Staels B. Peroxisome proliferator-activated receptor-gamma activation induces 11 beta-hydroxysteroid 
dehydrogenase type 1 activity in human alternative macrophages. Arteriosclerosis, thrombosis, and vascular biology. 2012; 32:677-685.

53. Vagnerova K, Loukotova J, Ergang P, Musilkova J, Miksik I, Pacha J. Peroxisome proliferator-activated receptorgamma stimulates 11 beta-hydroxysteroid dehydrogenase type 1 in rat vascular smooth muscle cells. Steroids. 2011; 76:577-581.

54. Shoulders CC. The FTO (fat mass and obesity-associated) gene: big in adipocyte lipolysis? Journal of lipid research. 2008; 49:495-496.

55. Fischer J, Koch L, Emmerling C, Vierkotten J, Peters T, Bruning JC, Ruther U. Inactivation of the Fto gene protects from obesity. Nature. 2009; 458:894-898.

56. Jin D, Sun J, Huang J, He Y, Yu A, Yu X, Yang Z. TNFalpha reduces g0s2 expression and stimulates lipolysis through PPAR-gamma inhibition in 3T3-L1 adipocytes. Cytokine. 2014; 69:196-205.
57. Bai L, Pang WJ, Yang YJ, Yang GS. Modulation of Sirt1 by resveratrol and nicotinamide alters proliferation and differentiation of pig preadipocytes. Mol Cell Biochem. 2008; 307:129-140.

58. Li B, Zerby HN, Lee K. Heart fatty acid binding protein is upregulated during porcine adipocyte development. J Anim Sci. 2007; 85:1651-1659.

59. Wang T, Li M, Guan J, Li P, Wang H, Guo Y, Shuai S, Li X. MicroRNAs miR-27a and miR-143 Regulate Porcine Adipocyte Lipid Metabolism. Int J Mol Sci. 2011; 12:7950-7959.

60. John B, Enright AJ, Aravin A, Tuschl T, Sander C, Marks DS. Human MicroRNA targets. PLoS Biol. 2004; 2:e363.

61. Lewis BP, Burge CB, Bartel DP. Conserved seed pairing, often flanked by adenosines, indicates that thousands of human genes are microRNA targets. Cell. 2005; 120:15-20. 